\title{
Seroprevalence of Toxoplasma gondii infection among Iranian pregnant women: a systematic review and meta-analysis
}

Mina Malary, ${ }^{1}$ Zeinab Hamzehgardeshi, ${ }^{2}$ Mahmood Moosazadeh, ${ }^{3}$ Mahdi Afshari, ${ }^{4}$ Imaneh Ahmadi, ${ }^{5}$ Iman Moghaddasifar ${ }^{1}$ and Motahareh Kheradmand ${ }^{3}$

${ }^{1}$ Student Research Committee; ${ }^{2}$ Department of Reproductive Health and Midwifery, School of Nursing and Midwifery; ${ }^{3}$ Health Sciences Research Centre, Faculty of Health; ${ }^{5}$ Department of Obstetrics \& Gynaecology, Emam Hospital, Mazandaran University of Medical Sciences, Sari, Islamic Republic of Iran (Correspondence to: Mahmood Moosazadeh: mmoosazadeh1351@gmail.com). ${ }^{2}$ Department of Community Medicine, School of Medicine, Zabol University of Medical Sciences, Zabol, Islamic Republic of Iran.

\begin{abstract}
Background: Toxoplasmosis is a great public health concern due to its capacity for prenatal transmission. Serologic studies have reported various estimates for seroprevalence of toxoplasmosis among Iranian pregnant women. Estimation of the pooled prevalence of this infection is necessary for policy-making.

Aims: The aim of this study was to estimate the prevalence of Toxoplasma gondii infection in Iranian pregnant women using systematic review and meta-analysis.

Methods: We searched national and international databases to identify relevant studies. To enhance the search sensitivity, we evaluated all references and interviewed relevant researchers and research centres. The final studies for meta-analysis were selected according to the quality assessment as well as inclusion/exclusion criteria. Because of the heterogeneity of the primary results, random effects models were used to estimate the pooled prevalence of T. gondii. We included 43 studies with a total sample size of 22644 in the meta-analysis.
\end{abstract}

Results: The pooled seroprevalence of overall toxoplasma infection, IgG antibody and IgM antibody was estimated at $41.3 \%$ (95\% CI: $35.8-46.8), 39.2 \%$ (95\% CI: 33.3-45.1) and 4.0\% (95\% CI: 3.1-4.9) respectively.

Conclusions: Our study showed that a considerable proportion of Iranian pregnant women are at high risk for toxoplasmosis.

Keywords: Toxoplasmosis, Toxoplasma gondii, infection, pregnancy, Iran

Citation: Malary M; Hamzehgardeshi Z; Moosazadeh M; Afshari M; Ahmadi I; Moghaddasifar I; et al. Seroprevalence of Toxoplasma gondii infection among Iranian pregnant women: a systematic review and meta-analysis. East Mediterr Health J. 2018;24(5):488-496. https://doi. $\operatorname{org} / 10.26719 / 2018.24 \cdot 5 \cdot 488$

Received: 09/09/15; accepted: 23/04/17

Copyright (C) World Health Organization (WHO) 2018. Some rights reserved. This work is available under the CC BY-NC-SA 3.0 IGO license (https:// creativecommons.org/licenses/by-nc-sa/3.o/igo).

\section{Introduction}

Toxoplasma gondii is an obligate intracellular protozoa with a complicated life cycle. This agent causes toxoplasmosis among humans and animals and is one of the most prevalent chronic infections, infecting onethird of the world population (1-5). Three main modes are responsible for fetal: consumption of including raw or semi-cooked meat, eating the oocytes defecated by cats and vertical transmission from an infected pregnant mother to her fetus $(6-7)$. Consideration of toxoplasmosis among pregnant women (owing to the risk of maternal transmission) and immunocompromised patients is of great importance for control programmes because infection can lead to serious pathologic outcomes among neonates with congenital toxoplasmosis and patients with immunodeficiency status (8-9). Knowing the burden of this infection will help health systems focus on prevention of risk factors.

A number of serological tests, such as the latex agglutination test, enzyme-linked immunosorbent assay (ELISA) and indirect fluorescence antibody test, have been used in the detection of antibodies against $T$. gondii in pregnant women. However, ELISA is the most commonly used diagnostic technique $(7,9)$.

Previous research has shown that toxoplasmosis infection was more common among those with history of close contact with cats, raw meat and vegetable consumption, and low education level (3). The most important benefit in the serology of toxoplasma is to detect whether the pregnant woman has acute infection or not, and if so, whether it occurred before pregnancy (10). The main problem in diagnosis among pregnant women is long-term antibody IgM, but T. gondii-specific antibody (IgM) does not necessarily indicate acute infection (11). In many cases, laboratory diagnosis of latent and acute T. gondii is based on detecting T. gondiispecific IgM and IgG antibodies (7). There are several serologic tests for anti-toxoplasma IgM and IgG, among which ELISA has maximum sensitivity and specificity (2). Chronic infection before pregnancy cannot be transmitted to the fetus, but acute untreated infection during pregnancy may lead to congenital toxoplasmosis with neonatal complications (6). The risk of transmission and the severity of fetal disease is based on gestational age and progressive antibody titration (8), so this risk 
varies between $0-9 \%$ (congenital infection during the first trimester) and 35-59\% (congenital infection during the third trimester) (12). Although the infection is usually asymptomatic or mild and self-limiting (fever, agitation, lymphadenopathy), infection occurring during pregnancy causes vertical transmission to the fetus (3) leading to pathologic complications such as hydrocephaly $(2,3)$, microcephaly, chorioretinitis (12), blindness $(2,3)$, mental retardation (2,12), epilepsy (12), jaundice (12), abortion $(2,3,12)$ and fetal death $(2,3,12)$. These complications can be accompanied by disabilities, reduced quality of life and a high socioeconomic burden (8).

Prevention of toxoplasmosis by screening is mandatory in some countries and is recommended in some others such as the United States of America and Canada (12). There is no routine screening programme for toxoplasmosis in the Islamic Republic of Iran (8) and there is no agreement on the best strategy for control of congenital toxoplasmosis (11) although treatment is very important, especially among immunocompromised patients and pregnant women (1).

Seroprevalence of toxoplasmosis has been reported as $30-60 \%$ in developed and developing countries (3). In an Iranian study, the incidence of congenital infection during pregnancy was reported to vary from 1 to 8 per 1000 pregnancies (8). According to a systematic review, the global annual incidence of congenital toxoplasmosis was estimated at 190100 , equivalent to a burden of 1.20 million disability-adjusted life years. This burden was greater in South America, some Eastern Mediterranean countries and other low-income countries (13).

Various primary studies have been published estimating the prevalence of toxoplasmosis among pregnant women in the Islamic Republic of Iran. Combining the results of these studies using systematic and meta-analytic methods will be of great importance. Therefore, in this study, we used the methods outlined above to estimate the pooled seroprevalence of toxoplasma antibodies among Iranian pregnant women.

\section{Methods}

\section{Data sources and search strategy}

The current study is a systematic review and metaanalysis of estimation of the seroprevalence of toxoplasmosis among Iranian pregnant women.

All electronic papers published in national and international databases including SID, Iranmedex, Magiran, Irandoc, Pubmed, Google Scholar, Scopus and Science Direct from 1990 until 10 March 2015 were enrolled in this study. The search strategy was performed using the following keywords as well as their Farsi equivalents: "toxoplasmosis", "Toxoplasma gondii", "toxoplasma infection", "T. gondii", "Iran", "pregnant", "seroepidemiology", "seroprevalence", "IgG antibody", " IgM antibody", "prevalence".

Searching was done from 11 to 20 March 2015. We used "OR" to identify studies with any of the keywords in their titles, abstracts and full texts. Limiting the search strategy was carried out applying "AND" to select studies with all of the required keywords. To provide more relevant keywords and studies leading to increased search sensitivity, we investigated all references used in these papers. One of the researchers randomly evaluated the search action and found that all required studies had been entered in the systematic review. Moreover, to find unpublished studies, we asked some well-known Iranian parasitologists working in the medical universities and infectious diseases research centres to introduce any relevant manuscripts which had not been published. However, we did not find any evidence during this phase of the search. All stages of the search as well as the followup actions were performed by 2 independent researchers. Any disagreement was settled by a third researcher.

\section{Selection of studies}

We extracted the full texts or abstracts of all documents collected during our search. During primary screening, repeated studies were excluded by investigation of the title and abstract. Secondary screening was conducted among studies selected during the primary phase to select more relevant studies with evaluation of the full text. In this stage, abstracts and full texts of the papers were investigated to exclude irrelevant and duplicated studies.

\section{Inclusion criteria}

All studies published in Farsi or English that achieved an adequate quality score ( $>8$ of 12 ) during the assessment process and also those estimating seroprevalence of toxoplasmosis, IgG and IgM titration among Iranian pregnant women were selected. These titrations were categorized according to the standards defined by the companies manufacturing the relevant substances (in most studies, antibody titration $>1.1 \mathrm{IU} / \mathrm{mL}$ for indirect fluorescence antibody test and ELISA was considered positive).

\section{Exclusion criteria}

Studies without estimations of IgG or IgM seroprevalence, studies without sample size reporting, abstracts submitted in congresses whose full texts were not available and case-control studies which could not report prevalence estimations were excluded from the study.

\section{Quality assessment}

After selecting relevant studies based on titles and contents, to select the documents of satisfactory quality, we applied the STROBE checklist (14). This checklist includes 22 items covering various components of the methodology such as sample size estimation and selection, study population, data collection methods, instrument for data collection, statistical analysis, geographical distribution of the study, aims of the study and appropriate illustration of the results based on the study objectives. Scores were determined from o to 44 . Based on the STROBE checklist assessment, documents were divided into to 3 groups: low quality, score <15.5; moderate quality, score 15.5- 29.5; and high quality, score 
30.0 - 44.0. Studies with score $<15.5$ were excluded from the meta-analysis.

\section{Data extraction}

Title of the study, first author's name, date and area of the study, total sample size, type of study, serologic method used, mean age of participants, seroprevalence of toxoplasmosis, prevalence of positive IgG and IgM (according to the cut-off points defined by the companies who manufactured the kits) were extracted from each of the selected studies. Extracted data were entered into Microsoft Excel for descriptive data analysis.

\section{Analysis}

All extracted data were entered into Stata, version 11 software. The standard error of toxoplasma seroprevalence for each study was calculated based on binomial distribution. The heterogeneity of the study results was determined using the Cochrane $(\mathrm{Q})$ test and I-squared (15). The random effects model was used to estimate the combined seroprevalence of toxoplasmosis as well as IgG/IgM seropositivity rates. The effects of potential factors in heterogeneity were assessed using the meta-regression method. We illustrated the point prevalence in forest plots, including the study weights (size of each box) and 95\% confidence interval (CI) (lines crossing the boxes).

\section{Results}

We found 12545 documents from national and international databanks using relevant keywords (12 541) and reviewing the references (4 papers). After limiting the search strategy and excluding duplicated papers, the number of relevant articles decreased to 1885. Reviewing the titles and abstracts, 1696 irrelevant records were removed. Out of the remaining papers, 146 were excluded after full text review and according to other exclusion and inclusion criteria. Finally, 43 papers $(6,7,9,12,16-54)$ were considered eligible for inclusion in the systematic review and meta-analysis (Table 1; Figure 1).

The final selection of papers was published from 1990 to 2015 (Table 1), 15 articles in English and 28 in Farsi. Type of study was explained in 34 papers, including 1 cohort and 33 descriptive and cross-sectional studies. The age of

\begin{tabular}{|c|c|c|c|c|c|c|c|c|c|}
\hline \multirow[t]{2}{*}{ Reference } & \multirow[t]{2}{*}{$\begin{array}{c}\text { Publication } \\
\text { year }\end{array}$} & \multirow[t]{2}{*}{$\begin{array}{l}\text { Publication } \\
\text { language }\end{array}$} & \multirow[t]{2}{*}{ Type of study } & \multirow[t]{2}{*}{$\begin{array}{l}\text { Quality } \\
\text { score }\end{array}$} & \multirow[t]{2}{*}{$\begin{array}{l}\text { Sample } \\
\text { size }\end{array}$} & \multirow[t]{2}{*}{$\begin{array}{l}\text { Serological } \\
\text { method }\end{array}$} & \multicolumn{3}{|c|}{$\begin{array}{c}\text { Prevalence of women with } \\
\text { positive antibody (\%) }\end{array}$} \\
\hline & & & & & & & IgG & $\operatorname{Ig} M$ & $\begin{array}{c}\operatorname{Ig} M+ \\
\operatorname{IgG}\end{array}$ \\
\hline Abdi (34) & 2008 & English & Cross-sectional & 26 & 553 & IFA & 44.8 & - & 44.8 \\
\hline Akhlaghi (48) & 2014 & English & - & 32 & 400 & ELISA & 29.0 & 1.0 & 30.0 \\
\hline Akhlaghi (13) & 2013 & English & Cross-sectional & 27 & 200 & IFA \& ELISA & 39.6 & 5.7 & $45 \cdot 3$ \\
\hline Alleyassin (51) & 1990 & English & - & 29 & 320 & IFA & 77.2 & - & 77.2 \\
\hline Anvaritafti (39) & 2012 & Farsi & Cross-sectional & 28 & 181 & ELISA & 32.0 & - & 32.0 \\
\hline Arbabi (54) & 2001 & Farsi & descriptive & 27 & 340 & IFA \% ELISA & - & - & 66.7 \\
\hline Athari (45) & 1994 & English & - & 26 & 495 & IFA & - & - & 32.7 \\
\hline Cheragipour (44) & 2010 & Farsi & Cross-sectional & 30 & 390 & ELISA & 23.6 & 7.4 & 31.0 \\
\hline Cheragipour (43) & 2009 & Farsi & Cross-sectional & 31 & 331 & ELISA & 28.7 & 10.5 & 39.2 \\
\hline Dalimiasl (40) & 2011 & Farsi & Cross-sectional & 31 & 300 & ELISA & 26.3 & 0.3 & 26.6 \\
\hline Ebrahimzadeh (52) & 2013 & Farsi & - & 30 & 221 & ELISA & 30.8 & 1.4 & 30.8 \\
\hline Eskandareian (37) & 2009 & Farsi & - & 29 & 255 & IFA & 62.7 & - & 62.7 \\
\hline Fallah (9) & 2008 & English & Cross-sectional & 32 & 576 & IFA & - & - & 33.5 \\
\hline Firozivand (41) & 2014 & English & Cross-sectional & 30 & 200 & ELISA & 39.5 & 2.5 & 41.0 \\
\hline Gasemi (35) & 2011 & Farsi & - & 27 & 127 & IFA & 47.2 & - & 47.2 \\
\hline Ghorvi (42) & 2002 & Farsi & - & 34 & 4120 & IFA & 67.6 & 0.4 & 68.0 \\
\hline Ghasemloo (47) & 2014 & English & Cross-sectional & 31 & 785 & ELISA & 31.1 & 0.0 & 31.1 \\
\hline Javadi (49) & 2014 & English & Cross-sectional & 29 & 195 & ELISA & 58.9 & 5.1 & 60.5 \\
\hline Hajsoleimani (7) & 2012 & English & - & 28 & 500 & ELISA & 37.2 & 1.4 & 38.6 \\
\hline Hamidi (50) & 2015 & English & Descriptive & 33 & 2523 & ELISA & 27.0 & 2.0 & 29.0 \\
\hline Sotudehjahromi (30) & 2002 & Farsi & Cross-sectional & 31 & 418 & ELISA & 34.2 & 7.9 & 39.7 \\
\hline Tabatabaei (31) & 2015 & English & Cross-sectional & 27 & 200 & ELISA & 29.0 & 2.0 & 31.0 \\
\hline Talari (32) & 2003 & Farsi & Descriptive & 28 & 270 & IFA & 26.7 & $5 \cdot 5$ & 32.2 \\
\hline Talari (33) & 2001 & Farsi & Descriptive & 31 & 562 & IFA & 33.8 & 7.8 & 41.6 \\
\hline Fooladvand (46) & 1998 & Farsi & Cross-sectional & 29 & 365 & ELISA & 37.8 & 5.7 & 43.6 \\
\hline Yad (6) & 2014 & English & Cross-sectional & 33 & 501 & ELISA & 27.8 & 1.3 & 29.1 \\
\hline
\end{tabular}


Table 1 Baseline characteristics of included studies in meta-analysis of seroprevalence of Toxoplasma gondii in Iranian pregnant women of (concluded)

\begin{tabular}{|c|c|c|c|c|c|c|c|c|c|}
\hline \multirow[t]{2}{*}{ Reference } & \multirow[t]{2}{*}{$\begin{array}{c}\text { Publication } \\
\text { year }\end{array}$} & \multirow[t]{2}{*}{$\begin{array}{l}\text { Publication } \\
\text { language }\end{array}$} & \multirow[t]{2}{*}{ Type of study } & \multirow[t]{2}{*}{$\begin{array}{l}\text { Quality } \\
\text { score }\end{array}$} & \multirow[t]{2}{*}{$\begin{array}{l}\text { Sample } \\
\text { size }\end{array}$} & \multirow[t]{2}{*}{$\begin{array}{l}\text { Serological } \\
\text { method }\end{array}$} & \multicolumn{3}{|c|}{$\begin{array}{c}\text { Prevalence of women with } \\
\text { positive antibody (\%) }\end{array}$} \\
\hline & & & & & & & IgG & IgM & $\begin{array}{l}\operatorname{Ig} M+ \\
\operatorname{IgG}\end{array}$ \\
\hline Jalai (16) & 2013 & Farsi & Cross-sectional & 34 & 211 & ELISA & 30.8 & 1.4 & 30.8 \\
\hline Babaie (36) & 2013 & English & - & 35 & 419 & ELISA & 34.4 & 18.8 & 34.4 \\
\hline Jamshidi (12) & 2012 & English & Cross-sectional & 35 & 600 & ELISA & 41.9 & 0.0 & 41.9 \\
\hline Kalantari (17) & 2013 & Farsi & Cross-sectional & 29 & 175 & ELISA & 60.6 & 0.0 & 60.6 \\
\hline Magsood (18) & 2013 & Farsi & Cross-sectional & 33 & 350 & ELISA & 30.0 & 2.9 & 32.9 \\
\hline $\begin{array}{l}\text { Manoochehrinaeini } \\
\text { (19) }\end{array}$ & 2004 & Farsi & Cross-sectional & 32 & 394 & IFA & 27.4 & 0.0 & 27.4 \\
\hline $\begin{array}{l}\text { Manoochehrinaeini } \\
(20)\end{array}$ & 2006 & Farsi & Cross-sectional & 30 & 384 & IFA & - & - & 27.6 \\
\hline Mardani (21) & 2004 & Farsi & Cross-sectional & 31 & 600 & ELISA & 41.0 & - & 41.0 \\
\hline Moosavi (22) & 2014 & Farsi & Cross-sectional & 28 & 185 & ELISA & 10.3 & 0.6 & 10.3 \\
\hline Parvizpoor (23) & 2010 & Farsi & Cross-sectional & 27 & 201 & ELISA & 43.2 & 28.3 & 55.0 \\
\hline Rasti (24) & 2014 & English & Cohort & 34 & 798 & ELISA & 42.7 & 0.6 & $43 \cdot 3$ \\
\hline Rostaminejad (53) & 2012 & Farsi & Descriptive & 32 & 496 & ELISA & 31.0 & 7.0 & 38.0 \\
\hline Saffar (25) & 1997 & Farsi & Descriptive & 33 & 612 & ELISA & 71.0 & - & 71.0 \\
\hline Sharbatkhori (26) & 2014 & English & Cross-sectional & 33 & 555 & ELISA & 39.8 & 3.4 & 40.4 \\
\hline Sharifi-mood (27) & 1998 & Farsi & Cross-sectional & 32 & 200 & IFA & 27.0 & 1.3 & 27.0 \\
\hline Siyadat Panah (28) & 2013 & English & Cross-sectional & 36 & 1057 & ELISA & 69.9 & $5 \cdot 3$ & 75.0 \\
\hline Sohrabi (29) & 2007 & Farsi & Cross-sectional & 31 & 79 & ELISA & 35.4 & - & 35.4 \\
\hline
\end{tabular}

IFA = indirect fluorescence antibody test.

ELISA = enzyme-linked immunosorbent assay.

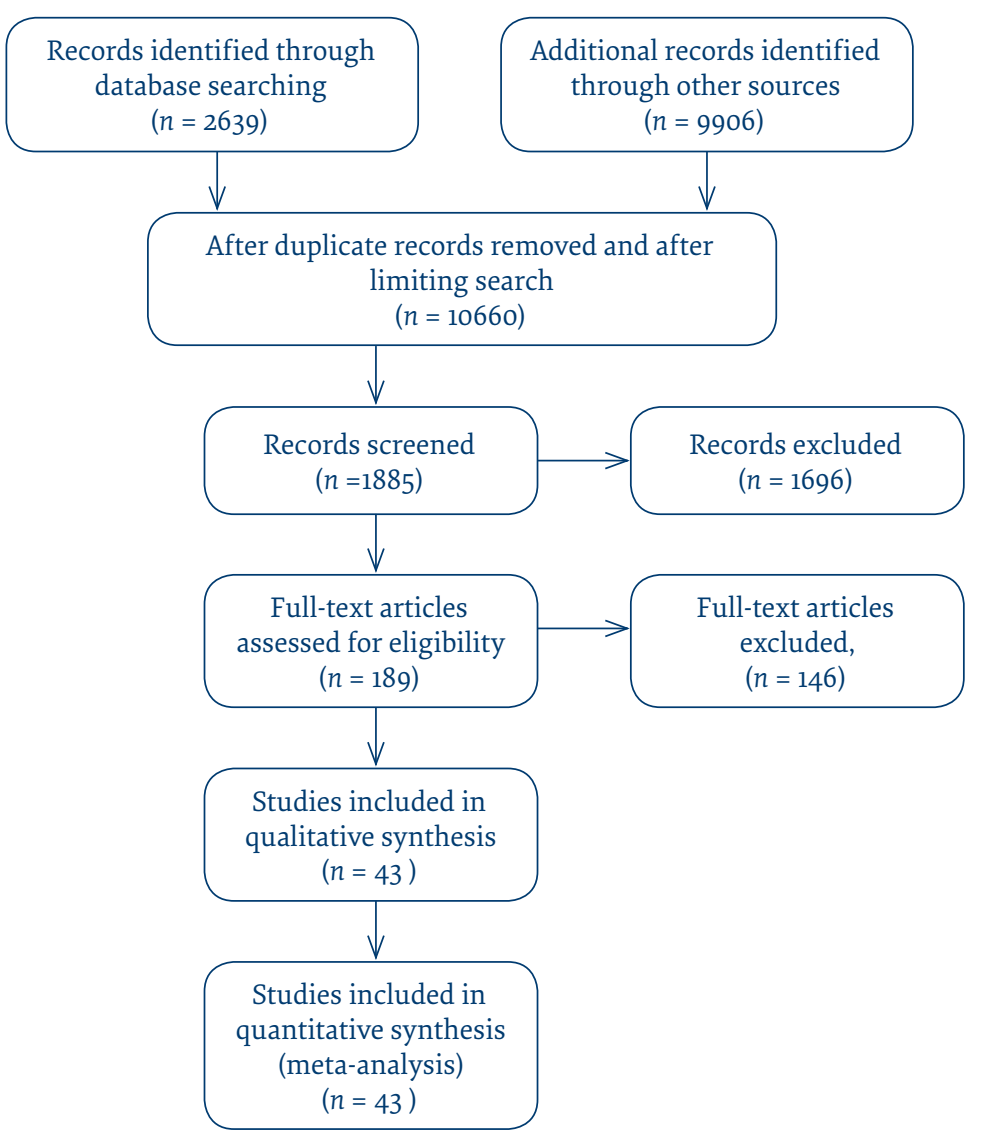


the participants was stated in 14 records, varying between 21.0 and 29.9 years. Serologic methods used for diagnosis of toxoplasma infection were indirect fluorescence antibody test (12 studies), ELISA (29 studies) and both (2 studies).

This meta-analysis involved 22644 pregnant women from different areas in the Islamic Republic of Iran. Minimum and maximum sample sizes were 72 and 4120 respectively. Raised IgG titration ranged between 10.3\% (23) and $77.2 \%(51)$ (10.8\% and 76.6\% respectively adjusting by Bayesian analysis). In addition, the prevalence of raised IgM varied from $0.0 \%(12,17,19,47)$ to $28.3 \%$ (23) (Bayesian adjusted values $0.4 \%$ and $11.9 \%$ ).

The pooled prevalence of toxoplasmosis among Iranian pregnant women was estimated at $41.3 \%$ using the random effects model (I-squared: $98.7 \%, \mathrm{Q}=3279.2$; $P<0.0001$ ) and $45.4 \%$ using the fixed model. According to the heterogeneity between the included studies, the results provided by the first model are acceptable. Values for the seroprevalence of raised IgG and IgM using the random effects model were $39.2 \%$ (I-squared: $98.7 \%, Q=$ 3178; $P<0.0001$ ) and $4.0 \%$ (I-squared: $94.3 \%, Q=453.8$; $P<0.0001)$ respectively. These high I-squares indicate considerable heterogeneity between the results.

Excluding the extreme results of some studies $(23,28,51,53)$, the total prevalence of toxoplasmosis, raised IgG prevalence and raised IgM prevalence were estimated at 40.3\% (I-squared: $98.3 \%, Q=2322 ; P<0.0001$ ), $38.9 \%$ (I-squared: $98.7 \%, Q=2751.3 ; P<0.0001$ ) and $3.1 \%$ (I-squared: 91.8\%, Q = 293; $P<0.0001$ ) respectively. Also, according to the meta-regression analysis, publication year had no significant effect in heterogeneity among primary studies.

\section{Discussion}

Our systematic review and meta-analysis showed that more than $41 \%$ of Iranian pregnant women are seropositive for T. gondii antibodies.

According to the results of the other systematic reviews and meta-analyses, Seroprevalence of toxoplasmosis among Iranian pregnant women is similar to that in the general population in the Islamic Republic of Iran, but is lower than the prevalence of toxoplasmosis in other high risk groups, e.g. immunocompromised groups such as patients with HIV/AIDS, or cancer and kidney transplant patients $(3,8,55)$ (Table 2). These differences are related to the different characteristics of the studies (general populations, immunocompromised groups, different nutritional behaviours, geographical conditions and various diagnostic serologic methods).

Some research has shown that prevalence of toxoplasmosis is higher in temperate climate regions and lower in cold and hot and dry areas. Inappropriate conditions for growth and development of oocytes in the areas with hot and dry climates may be an explanation for low prevalence of toxoplasmosis in such areas $(9,22)$.

Prevalence of toxoplasmosis among pregnant women in a Chinese study was less than $10 \%(56)$, which was

\begin{tabular}{|c|c|c|c|}
\hline \multicolumn{4}{|c|}{$\begin{array}{l}\text { Table } 2 \text { Seroprevalence of Toxoplasma gondii in the Iranian } \\
\text { population group based on other meta-analyses }\end{array}$} \\
\hline Reference & $\begin{array}{l}\text { Population } \\
\text { group }\end{array}$ & $\begin{array}{l}\text { Sample } \\
\text { size (No.) }\end{array}$ & $\begin{array}{c}\text { Pooled } \\
\text { estimate based } \\
\text { on random } \\
\text { effect }(\%)\end{array}$ \\
\hline Daryani (3) & $\begin{array}{l}\text { General } \\
\text { population }\end{array}$ & 52294 & 39.3 \\
\hline Borna (8) & $\begin{array}{l}\text { Women of } \\
\text { childbearing } \\
\text { age }\end{array}$ & 13480 & 39.9 \\
\hline $\begin{array}{l}\text { Ahmadpour } \\
\text { (55) }\end{array}$ & $\begin{array}{l}\text { HIV/AIDS } \\
\text { patients }\end{array}$ & 1032 & 50.1 \\
\hline $\begin{array}{l}\text { Ahmadpour } \\
\text { (55) }\end{array}$ & Cancer patients & 1071 & 45.1 \\
\hline $\begin{array}{l}\text { Ahmadpour } \\
\text { (55) }\end{array}$ & $\begin{array}{l}\text { Transplant } \\
\text { patients }\end{array}$ & 702 & 55.1 \\
\hline
\end{tabular}

lower than the rates estimated in our meta-analysis. That was also the case for a study carried out in Norway which estimated the IgG seroprevalence as 9.3\% (57). Out of 760 pregnant women investigated in a study in Thailand, $25 \%$ were seropositive for toxoplasmosis (22\% IgG positive and $3 \% \operatorname{IgG}+\operatorname{IgM}$ positive) (58). Two different studies, reported the seroprevalence of Korean pregnant women as $3.7 \%(59)$ and $0.8 \%(60)$.

Seroprevalence of IgG and IgM among Indian pregnant women was $45 \%$ and $3.3 \%$ respectively (61) corresponding values for 1149 Turkish pregnant women were $60.4 \%$ and $3.0 \%$ respectively (62). A systematic review conducted in Brazil indicated that more than 50\% of primary school children as well as $50-80 \%$ of women during the reproductive period were seropositive for toxoplasmosis (63). The variability was due to multiple factors such as contact with faeces of infected cats, adult oocyte consumption, nutritional behaviours and climate.

Congenital toxoplasmosis is one of the most important fetal diseases and is also a major factor for developing mental retardation. Infection during pregnancy can facilitate the development of such pathologies. During the first months of pregnancy particularly, T. gondii infection can cause abortion and even stillbirth (64). Incidence of the congenital infection during pregnancy was estimated as 1-8 per 1000 pregnancies in a 2013 Iranian review (8). Therefore, in IgM-seropositive pregnant women, a treatment regimen for acute infection is necessary to prevent the development of congenital toxoplasmosis and its complications. Diagnosis of T. gondii infection among pregnant women in populations with low prevalence is critical, however, it is not possible for all pregnant women and is restricted to suspected cases. Therefore, routine screening among low-risk pregnant women is not recommended; it is only suggested for those with a higher risk of infection (65).

Unfortunately, we could not perform a meta-analysis based on the different climatic areas of the Islamic Republic of Iran because of the low number of studies 
conducted in temperate and cold regions. Variations in the primary studies due to factors such as different cut-off points for positive IgG, sampling methods, questionnaires used, situations for data collection, sample sizes and date of studies are other limitations of our study.

\section{Acknowledgments}

The authors thank the Student Research Committee and Deputy for Research of Mazandaran University of Medical Sciences for their kind cooperation.

Funding: This study was financially supported by Mazandaran University of Medical Sciences.

Competing interests: None declared.

\section{Séroprévalence de l'infection à Toxoplasma gondii chez les femmes enceintes iraniennes : examen systématique et méta-analyse}

\section{Résumé}

Contexte : La toxoplasmose est une importante préoccupation de santé publique du fait de sa capacité de transmission prénatale. Différentes études sérologiques ont fait état de séroprévalences de la toxoplasmose variées chez les femmes enceintes iraniennes. L'estimation de la prévalence globale de cette infection est nécessaire en vue de l'élaboration de politiques.

Objectif : Le but de la présente étude est d'estimer la prévalence de l'infection à Toxoplasma gondii en République islamique d'Iran au moyen de l'examen systématique et des méthodes de méta-analyse.

Méthodes : Nous avons effectué des recherches dans différentes bases de données nationales et internationales pour identifier les études pertinentes. Afin de renforcer la sensibilité de la recherche, nous avons évalué toutes les références et interrogé les chercheurs et centres de recherche concernés. Les études finales requises pour la méta-analyse ont été sélectionnées en fonction des résultats de l'évaluation de la qualité ainsi que des critères d'inclusion/exclusion. En raison de l'hétérogénéité des résultats primaires, des modèles à effets aléatoires ont été utilisés pour estimer la prévalence globale de Toxoplasma gondii. Nous avons recruté 43 études, la taille totale de l'échantillon étant de 22644 dans la méta-analyse.

Résultats : Les séroprévalences globales de l'infection à Toxoplasma globale, des anticorps IgG et des anticorps IgM ont été estimées à 41,3\% (IC à $95 \%$ : 35,8-46,8), 39,2 \% (IC à $95 \%$ : 33,3-45,1) et 4,0\% (IC à 95\%:3,1-4,9) respectivement.

Conclusion : Notre étude a montré qu'une proportion considérable de femmes enceintes iraniennes courent un risque élevé de toxoplasmose.

$$
\begin{aligned}
& \text { مستوى الانتشار المصلي لعدوى المقوسة العوندية بين النساء الحوامل الإير انيات: استعر اض منهجي وتحليل وصفي }
\end{aligned}
$$

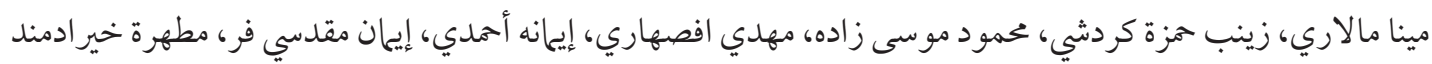

$$
\begin{aligned}
& \text { الخلاصة }
\end{aligned}
$$

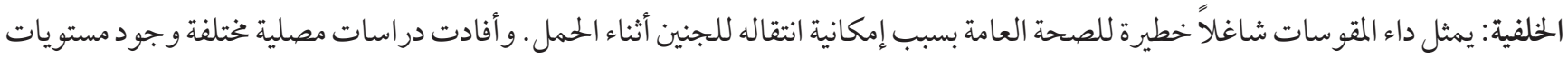

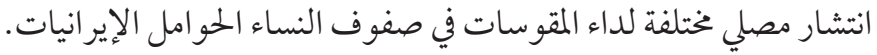

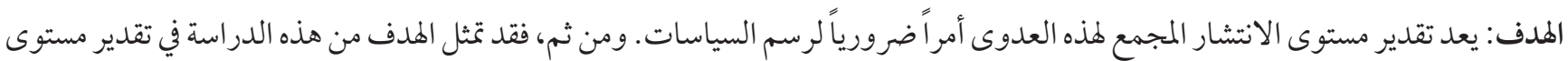

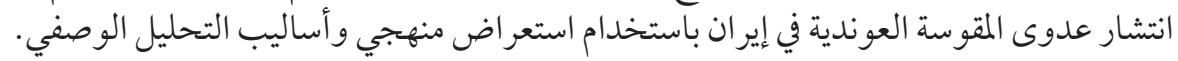

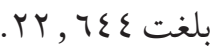

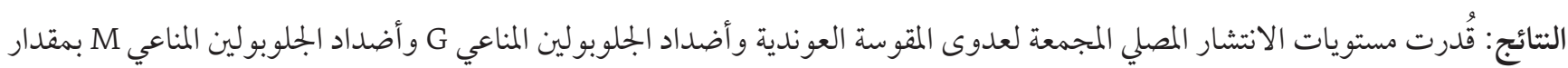

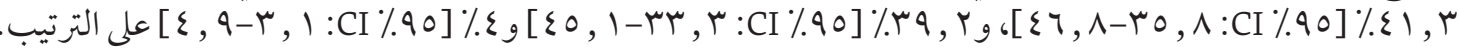

$$
\begin{aligned}
& \text { الاستتاج: أظهرت دراستنا أن نسبة كبيرة من النساء الحو امل الإيرانيات تواجهن مخاطر مرتفعة للإصابة بعدوى المقوسة العوندية. }
\end{aligned}
$$




\section{References}

1. Galvan-Ramirez ML, Troyo R, Roman S, Calvillo-Sanchez C, Bernal-Redondo R. A systematic review and meta-analysis of Toxoplasma gondii infection among the Mexican population. Parasit Vectors. 2012 11 26;5(1):271. https://doi.org/10.1186/1756-33055-271 PMID:23181616

2. Saki J, Mohammadpour N, Moramezi F, Khademvatan S. Seroprevalence of Toxoplasma gondii in women who have aborted in comparison with the women with normal delivery in Ahvaz, southwest of Iran. Sci World J. 2015;2015:764369. https://doi. org/10.1155/2015/764369 PMID:25699288

3. Daryani A, Sarvi S, Aarabi M, Mizani A, Ahmadpour E, Shokri A, et al. Seroprevalence of Toxoplasma gondii in the Iranian general population: a systematic review and meta-analysis. Acta Trop. 2014 Sep;137:185-94. https://doi.org/10.1016/j. actatropica.2014.05.015 PMID:24887263

4. Dubey JP, Hotea I, Olariu TR, Jones JL, Dărăbuş G. Epidemiological review of toxoplasmosis in humans and animals in Romania. Parasitology. 2014 Mar;141(3):311-25. https://doi.org/10.1017/So031182013001509 PMID:24553077

5. Saadatnia G, Golkar M. A review on human toxoplasmosis. Scand J Infect Dis. 2012 Nov;44(11):805-14. https://doi.org/10.3109/003 65548.2012.693197 PMID:22831461.

6. Yad MJ, Jomehzadeh N, Jafar Sameri M, Noorshahi N. Seroprevalence of Anti- Toxoplasma gondii Antibodies Among Pregnant Woman in South Khuzestan, Iran. Jundishapur J Microbiol. 2014 May;7(5):e9998. https://doi.org/10.5812/jjm.9998 PMID:25147724

7. Hajsoleimani F, Ataeian A, Nourian A, Mazloomzadeh S. Seroprevalence of Toxoplasma gondii in pregnant women and bioassay of IgM positive cases in Zanjan, Northwest of Iran. Iran J Parasitol. 2012;7(2):82-6. PMID:23109950

8. Borna S, Shariat M, Fallahi M, Janani L. Prevalence of immunity to toxoplasmosis among Iranian childbearing age women: systematic review and meta-analysis. Iran J Reprod Med. 2013 Nov;11(11):861-8. PMID:24639709

9. Fallah M, Rabiee S, Matini M, Taherkhani H. Seroepidemiology of toxoplasmosis in primigravida women in Hamadan, Islamic Republic of Iran, 2004. East Mediterr Health J. 2008 Jan-Feb;14(1):163-71. PMID:18557464

10. Golkar M, Rafati S, Abdel-Latif MS, Brenier-Pinchart M-P, Fricker-Hidalgo H, Sima BK, et al. The dense granule protein GRA2, a new marker for the serodiagnosis of acute Toxoplasma infection: comparison of sera collected in both France and Iran from pregnant women. Diagn Microbiol Infect Dis. 2007 Aug;58(4):419-26. https://doi.org/10.1016/j.diagmicrobio.2007.03.003 PMID:17509806

11. Petersen E. Toxoplasmosis. Semin Fetal Neonatal Med. 2007;12(3):214-23. https://doi.org/10.1016/j.siny.2007.01.011 PMID:17321812

12. Jamshidi Makiani M, Davoodian P, Golsha R, Dehghani M. Seroepidemiology and risk factors of Toxoplasmosis in the first trimester among pregnant women. Int Electronic J Med. 2012;1(2):12-7

13. Torgerson PR, Mastroiacovo P. The global burden of congenital toxoplasmosis: a systematic review. Bull World Health Organ. 2013 Jul 1;91(7):501-8. https://doi.org/10.2471/BLT.12.111732 PMID:23825877

14. von Elm E, Altman DG, Egger M, Pocock SJ, Gøtzsche PC, Vandenbroucke JP; STROBE Initiative. The Strengthening the Reporting of Observational Studies in Epidemiology (STROBE) statement: guidelines for reporting observational studies. Prev Med. 2007 Oct;45(4):247-51. https://doi.org/10.1016/j.ypmed.2007.08.012 PMID:17950122

15. Higgins JP, Thompson SG. Quantifying heterogeneity in a meta-analysis. Stat Med. 2002 Jun 15;21(11):1539-58. https://doi. org/10.1002/sim.1186 PMID:12111919

16. Jalai N, Olfatian Gilan b, Tavasoli A, Tanomand A, Reaghi S. Seroepidemiology of toxoplasmosis among pregnant women referring to health center laboratories of Bojnurd in 2013. J North Khorasan Univ of Med Sciences. 2013;5(5):1101-5.

17. Kalantari N, Ghaffari S, Bayani M, Agapour R, Zeinalzadeh M, Gavipanjeh F, et al. Serological study of toxoplasmosis in pregnant women in the city of Babol, northern Iran, 2012-2013. J Ilam Univ of Med Sciences. 2014;22:102-8.

18. Maghsood A, Fallah M, Moradi-Sardareh H, Shanazi H, Hosseini-Zijoud S-M, Moradi Y. Seroepidemiology of toxoplasmosis in pregnant women referring to health centers in the city of Hamadan in 1391. Pajouhan Sci J. 2013;11(2):3-8.

19. Manouchehri -Naeini K, Deris F, Zebardast N. The immunity status of the rural pregnant women in Chaharmahal and Bakhtyari province against Toxoplasma infection 2001-2002. J Shahrekord Univ of Med Sciences. 2004;6(3):63-72.

20. Manouchehri-Naeini K, Keshavarz H, Abdizadeh-Dehkordi R, Zebardast N, Kheiri S, Khalafian P. Seroprevalence of antitoxoplasma antibodies among pregnant women from Chaharmahal and Bakhtyari province using indirect immunoflurescent in 2006-2007. Shahrekord Uni Med Sci J. 2006;8(4):74-80.

21. Mardani A, Keshavarz H. Comparison of the two methods, IFA and ELISA, in seroepidemiological study of toxoplasma infection in pregnant women of Qom City. J Sch Public Health Inst Public Health Res. 2004;2(3):57-64.

22. Mousavi M, Jamshidi A, Reisi JM. Serological study of toxoplasmosis among pregnant women of Nikshahr in 2012. Razi J Med Sci. 2014;21(123):45-53.

23. Parvizpour F, Hajighasemlo S, Hasani S, Olfati L, Bahmani A, Hoseini F, et al. Toxoplasmosis infection in the pregnant women in the first half of pregnancy, in Kamyaran in 2008. Sci J Kurdistan Univ Med Sci. 2010;15(1):72-8.

24. Rasti S, Hooshyar H, Arbabi M, Fatahian A, Behrashi M, Talebian A, et al. Frequency of toxoplasma infection among pregnant women and their newborn in Kashan, Iran. Zahedan J Res Med Sci. 2014:29-32.

25. Saffar M, Ajami A, Mamizade N. Seroprevalence of toxoplasma infection in pregnant women in Sari. J School Med Sci of Mazandaran. 1997;9(24):25-9. 
26. Sharbatkhori M, Dadi Moghaddam Y, Pagheh AS, Mohammadi R, Hedayat Mofidi H, Shojaee S. Seroprevalence of Toxoplasma gondii infections in pregnant women in Gorgan City, Golestan Province, Northern Iran-2012. Iran J Parasitol. 2014 AprJun;9(2):181-7. PMID:25848383

27. Sharifi-Mood B, Hashemi-Shahri M, Naderi M. Investigation of the prevalence of toxoplasma antibodies in women during pregnancy in child and mother's clinic in zahedan. Iranian J Obst,Gynecol Infertil. 2000-2001;3(5\&6):72-5.

28. Siyadatpanah A, Soufiani KB, Barzegar G, Gharachorlou A, Zeydi AE. Seroprevalence of Toxoplasma gondii infection among pregnant women in Amol, Northern Iran. Life Sci J. 2013;10(2s):164-8.

29. Sohrabi A, Samarbafzadeh A, Makvandi M, Maraghi S, Razi T, Darban D. Seroepidemiological study of Parvovirus B19, Toxoplasma gondii and Chlamydia trachomatis in pregnant women visiting the maternity ward of Imam Khomeini Hospital in Ahwaz. J Reprod Infertil. 2007;4(3):171-5.

30. Sotudeh Jahromi A, Safa O, Zare S, Davoudian P, Farshidfar G. Anti-toxoplasmosis antibodies prevalence among pregnant women admitted to hospital in Bandar Abbas. J Hormozgan Univ Med Sci. 2002;6(4):25-30.

31. Tabatabaie F, Mafi M, Golestani M, Shahmohammad N, Mafi H, Maleki F. Seroprevalence of and risk factors for Toxoplasma gondii among pregnant women in Abyek township of Qazvin Province, Iran (2013). Asian J Pharmaceut Clin Res. 2015;8(1):1-3.

32. Talari SA, Hejazi SH, Rasti S, Shadzi S. Seroepidemiology of Toxoplasma gondii in pregnant females referring to Ashrafi Isfahani Hospital in Khomeinishahr, 1998-2000. KAUMS J (FEYZ). 2003;6(4):32-7.

33. Talari S, Namaki S, Khorshidi Mal Ahmadi A. Seroepidemiology of toxoplasmosis in pregnant women admitted to hospital in Kashan Shabihkhani, 1990-1993. J Faculty of Med. 2001;25(4):243-8.

34. Abdi J, Shojaee S, Mirzaee A, Keshavarz H. Seroprevalence of toxoplasmosis in pregnant women in Ilam province, Iran. Iran J Parasitol. 2008;3(2):34-7.

35. Ghasemi A, Razaghi Manesh M, Alidusti H, Bahavarnia R, Baradaran H. Seroprevalence of antibodies against Toxoplasma in pregnant women in Esfahan with emphasis on cats on transmission of the disease. J Modern Vet Res. 2011;3(9):23-7.

36. Babaie J, Amiri S, Mostafavi E, Hassan N, Lotfi P, Esmaeili Rastaghi AR, et al. Seroprevalence and risk factors for Toxoplasma gondii infection among pregnant women in Northeast Iran. Clin Vaccine Immunol. 2013 Nov;20(11):1771-3. https://doi.org/10.1128/ CVI.00125-13 PMID:24006138

37. Eskandarian A. Seroepidemiology of toxoplasmosis in admitted pregnant women in maternity ward of Kowsar teaching and cure center in Qazvin-2006. Iran. J. Med. Microbiol. 2009;3(2):73-9.

38. Akhlaghi L, Shirbazou S, Maleki F, Keyghobadi A, Tabaraei Y, Tabatabaie F. Seroepidemiology of toxoplasma infection in pregnant women in Qom Province, Iran (2010). Life Sci J. 2013;10(7s):322-5.

39. Anvaritafti M, Ghafourzadeh M. Seroepidemiology of Toxoplasma infection in pregnant women in Yazd in 2012. Tolue Behdasht. 2014;13(3):116-25.

40. Dalimiasl A, Arshad M. Sero-epidemiology of toxoplasma infection in pregnant women referred to Al Zahra Hospital in Tabriz. Sci J Ilam Univ Med Sci. 2011;20(3):55-62.

41. Firozivand Y, Garedaghi Y. Seroprevalence of Toxoplasma gondii infection in pregnant women in Miandoab city, Iran. Indian J Fundamental Appl Life Sci. 2014;4(3):449-54.

42. Gharavi M. Seroepidemiological survey of toxoplasmosis in pregnant women in Tehran. Hakim Res J. 2002;5(2):91-8.

43. Cheraghipour K, Sheikhian A, Maghsood A, Hejazi Z, Rostaminezhad M, Moradpour K. Prevalence of toxoplasmosis in pregnant women in urban and rural health centers in Aleshtar in 2008. J Lorestan Univ Med Sci. 2009;11(4):65-73.

44. Cheraghipour K, Taherkhani H, Falah Mohammad S, Sardarian K, Rostamnezhad M, et al. Seroprevalence of toxoplasmosis in pregnant women admitted to the health centers of Khorram-Abad City, Iran. Hamadan Univ Med Sci. 2010;17(3):46-51.

45. Athari A, Shojaeian S, ELIASI O, Delfani K. Seroprevalence of toxoplasma antibodies among pregnant women in Kerman Shah. Med J Islamic Republic of Iran (MJIRI). 1994;8(2):93-5.

46. Foladvand M, Jaafary S. Seroprevalence of anti-toxoplasma antibodies in pregnant women in Bushehr. Iran J Parasitol. 1998;3(2):113-6.

47. Ghasemloo H, Ghomashlooyan M, Hooshyar H. Seroprevalence of Toxoplasma gondii infection among pregnant women admitted at Shahid Akbar Abadi hospital, Tehran, Iran, 2010-2013. J Med Microbiol Infec Dis. 2014;1(2):16-9.

48. Akhlaghi L, Ghasemi A, Hadighi R, Tabatabaie F. Study of seroprevalence and risk factors for Toxoplasma gondii among pregnant women in Karaj township of Alborz province [2013]. J Entomol Zool Stud. 2014;2(6):217-9.

49. Javadi EHS, Haghdoost M, Taghizadeh S, Oweysee H. Toxoplasma infection in pregnancy: Diagnosis and treatment. Int J Curr Res Acad Rev. 2014;2(8):274-80.

50. Hamidi M, Khulojini M, Azizian R, Bashiri H, Ahanchian A, Babanejad M, et al. Seroprevalence of toxoplasmosis among women referring to Shahid Beheshti Hospital, Hamadan, Iran. Novelty in Biomed. 2015;3(1):1-5.

51. Alleyassin F, Moatari A, Zare F. The prevalence of Toxoplasma gondii antibodies in pregnant women in Shiraz. Iran J Med Sci. 1990;1(15):17-3.

52. Ebrahimzadeh A, Mohammadi S, Davoodi T, Salimi Khorashad A, Jamshidi A. Seroepidemiology of toxoplasmosis among pregnant women referring to the reference laboratory of Zahedan, Iran (2011). Med Laboratory J. 2013;7(3):61-8. 
53. Rostami Nejad M, Fazeli Z, Nazemalhosseini Mojarad E, Cheraghipour K, Pourhoseingholi M, Rostami K, et al. Prevalence of celiac disease and toxoplasmosis during pregnancy. Med Sci J Islamic Azad Univ. 2013; 22 (4):288-293.

54. Arbabi M, Talari S. Seroprevalence of toxoplasma infection in pregnant women in Kashan Iran. Feiz J. 2001;22:28-38.

55. Ahmadpour E, Daryani A, Sharif M, Sarvi S, Aarabi M, Mizani A, et al. Toxoplasmosis in immunocompromised patients in Iran: a systematic review and meta-analysis. J Infect Dev Ctries. 201412 15;8(12):1503-10. https://doi.org/10.3855/jidc.4796 PMID:25500647

56. Gao XJ, Zhao ZJ, He ZH, Wang T, Yang TB, Chen XG, et al. Toxoplasma gondii infection in pregnant women in China. Parasitology. 2012 Feb;139(2):139-47. https://doi.org/10.1017/So031182011001880 PMID:22054357

57. Findal G, Barlinn R, Sandven I, Stray-Pedersen B, Nordbø SA, Samdal HH, et al. Toxoplasma prevalence among pregnant women in Norway: a cross-sectional study. APMIS. 2015 Apr;123(4):321-5. https://doi.org/10.1111/apm.12354 PMID:25628065

58. Andiappan H, Nissapatorn V, Sawangjaroen N, Chemoh W, Lau YL, Kumar T, et al. Toxoplasma infection in pregnant women: a current status in Songklanagarind hospital, southern Thailand. Parasit Vectors. 201405 22;7(1):239. https://doi.org/10.1186/17563305-7-239 PMID:24886651

59. Han K, Shin DW, Lee TY, Lee YH. Seroprevalence of Toxoplasma gondii infection and risk factors associated with seropositivity of pregnant women in Korea. J Parasitol. 2008 Aug;94(4):963-5. https://doi.org/10.1645/GE-1435.1 PMID:18576787

6o. Song KJ, Shin JC, Shin HJ, Nam HW. Seroprevalence of toxoplasmosis in Korean pregnant women. Korean J Parasitol. 2005 Jun;43(2):69-71. https://doi.org/10.3347/kjp.2005.43.2.69 PMID:15951643

61. Singh S, Pandit AJ. Incidence and prevalence of toxoplasmosis in Indian pregnant women: a prospective study. Am J Reprod Immunol. 2004 Oct;52(4):276-83. https://doi.org/10.1111/j.1600-0897.2004.00222.x PMID:15494049

62. Harma M, Harma M, Gungen N, Demir N. Toxoplasmosis in pregnant women in Sanliurfa, Southeastern Anatolia City, Turkey. J Egypt Soc Parasitol. 2004 Aug;34(2):519-25. PMID:15287175

63. Dubey JP, Lago EG, Gennari SM, Su C, Jones JL. Toxoplasmosis in humans and animals in Brazil: high prevalence, high burden of disease, and epidemiology. Parasitology. 2012 Sep;139(11):1375-424. https://doi.org/10.1017/Soo31182012000765 PMID:22776427.

64. Saki J, Mohammadpour N, Moramezi F, Khademvatan S. Seroprevalence of Toxoplasma gondii in women who have aborted in comparison with the women with normal delivery in Ahvaz, Southwest of Iran. Scientific World J. 2015;2015:1-4.

65. Paquet C, Yudin MH, Yudin MH, Allen VM, Bouchard C, Boucher M, et al.; Society of Obstetricians and Gynaecologists of Canada. Toxoplasmosis in pregnancy: prevention, screening, and treatment. J Obstet Gynaecol Can. 2013 Jan;35(1):78-81. https:// doi.org/10.1016/S1701-2163(15)31053-7 PMID:23343802 